\title{
Analisis Dinamik pada Model Pengendalian Persediaan Dua Produk Berbeda dengan Kapasitas Produksi Terbatas Serta Inisiatif Tim Sales Bersama
}

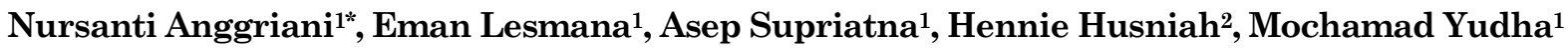

\begin{abstract}
In this paper we discuss a mathematical model of inventory control policy based on local stability analysis using a system dynamics approach. It is assumed that the production capacity and the maximum production capacity has an upper limit but with sufficient availability of raw materials so that the production occurs continuously without stock out. The model is intended to meet the market equilibrium by determining the optimal number of agents in a team of salesman, the level of inventory, and the level of production capacity, so that the net income is maximized. We use the Pontryagin Maximum Principle to find the optimal control of the system. Finally some numerical simulations are performed to give a sensitivity analysis of the inventory control policy to the parameters involved in the system.
\end{abstract}

Keywords: Inventory control, dynamic systems, inventory products, limited production capacity, sales team initiatives, local stability analysis, optimal control, sensitivity analysis.

\section{Pendahuluan}

Persediaan adalah sumber daya yang menganggur untuk menunggu proses lebih lanjut seperti suatu kegiatan produksi pada sistem manufaktur dan kegiatan pemasaran dalam sistem distribusi (Rangkuti [1]). Menurut Rangkuti, fungsi utama dari persediaan adalah menjamin kelancaran mekanisme pemenuhan permintaan barang sesuai dengan kebutuhan konsumen sehingga sistem yang dikelola dapat mencapai kinerja (performance) yang optimal. Selain itu juga dapat berdampak menekan serendah-rendahnya biaya produksi dari suatu perusahaan. Sistem yang dikelola dapat mencapai kinerja yang optimal dengan cara melakukan perencanaan produksi terkait pengendalian persediaan yang baik dari waktu ke waktu. Analisis penentuan tingkat persediaan dapat dilakukan melalui pemodelan. Sebagai contoh, Ghosh dan Chaudhuri [2] mengembangkan model persediaan dengan dua tingkat penyimpanan. Datta dan Pal [3] memodifikasi model Baker dan Urban [4] dengan memperhatikan tingkat permintaan ketika barang habis dimana faktor-faktor lain yang mempengaruhi diasumsikan konstan.

Banyak faktor yang mempengaruhi ketertarikan pelanggan akan suatu produk. Pada umumnya

\footnotetext{
1 Fakultas Matematika dan Ilmu Pengetahuan Alam, Program Studi Matematika, Universitas Padjadjaran, Jl. Ir. Soekarno Jatinangor 45363, Indonesia. Email: n_anggriani@unpad.ac.id dan nursanti.anggriani@gmail.com

${ }^{2}$ Fakultas Teknik, Program Studi Teknik Industri, Universitas Langlangbuana, Л. Karapitan, Bandung 40261, Indonesia

* Penulis korespondensi
}

banyaknya persediaan barang konsumen yang ditampilkan di pusat perbelanjaan akan menarik pelanggan untuk membeli lebih banyak, artinya bahwa pelanggan memiliki cakupan untuk memilih desain atau kualitas produk yang lebih baik di antara besarnya persediaan yang tersedia (Sana, [5]). Selain itu juga ketertarikan pelanggan tidak lepas dari usaha tim sales untuk menarik pelanggan dengan upaya promosi. Usaha seperti ini disebut sebagai inisiatif tim sales (Sana, [5]). Terdapat hubungan antara inisiatif tim sales ini dengan tuntutan untuk mempertahankan persediaan produk terkait guna memenuhi permintaan konsumen. Namun untuk memenuhi tuntutan tersebut, pada kenyataanya terkadang terdapat berbagai keterbatasan yang terjadi pada sistem, seperti dalam hal kapasitas produksi serta bahan baku. Faktor-faktor ini semestinya masuk dalam analisis penentuan tingkat persediaan suatu produk.

Penelitian seperti ini sudah mulai dilakukan oleh Sana pada tahun 2011 melalui pendekatan sistem dinamik. Sana membuat penelitian yang membahas mengenai kebijakan pengendalian persediaan yang dipengaruhi inisiatif salesman bersama untuk dua produk yang identik (Sana, [6]). Pada tahun 2011 juga, Sana mengembangkan penelitian lanjutan dengan menambahkan harga produk yang diproduksi pada dua produk yang serupa (Sana, [7]). Selanjutnya pada tahun 2012, ditambahkan asumsi bahwa pengaruh inisiatif salesmen pada dua produk yang serupa tersebut bersifat masing-masing (Sana, [8]). Pada 2013 pengembangan penelitian dilakukan kembali dengan pendekatan kompartemen yang berbeda dari tahun sebelumnya. Sana melakukan 
penelitian dengan menggunakan dua kompartemen yaitu tingkat persediaan dan kapasitas produksi dari suatu produk dengan pengaruh inisiatif tim sales (Sana [5]). Penelitian tersebut mengembangkan model pengendalian persediaan secara deterministik. Penelitian yang dilakukan oleh Sana dari tahun 2011 sampai dengan 2013 menggunakan model dengan dua jenis produk yang serupa (similar product).

Dalam memodelkan dua produk yang serupa, Sana memberikan asumsi bahwa permintaan produk pertama dipengaruhi secara positif oleh usaha bersama (joint effort) dan dipengaruhi secara negatif oleh jumlah persediaan produk kedua yang sejenis (Sana, [6]). Asumsi yang serupa juga berlaku untuk permintaan produk yang kedua. Asumsi yang sama dipakai pada Sana untuk dua produk yang serupa tetapi dengan model yang berbeda (Sana [7]). Dalam kedua paper tersebut dicari besaran usaha bersama optimal yang dapat memaksimumkan total profit dari kedua produk tersebut. Sana mengembangkan sebuah model untuk produk serupa tetapi dengan usaha yang dilakukan oleh tim sales hanya untuk masing-masing produk saja secara terpisah (Sana, [8]). Keseluruhan model tersebut di atas mengasumsikan bahwa laju pengadaan (replenishment) dipengaruhi oleh kapasitas display yang konstan. Selanjutnya Sana membuat model pengendalian persedian untuk suatu produk dengan asumsi bahwa laju pengadaan dipengaruhi oleh kapasitas produksi dengan laju kapasitas produksi yang tidak konstan (Sana [5]). Pada makalah ini kami membuat sebuah model pengendalian persedian untuk dua produk yang berbeda dengan memperluas Sana [5] dengan asumsi bahwa permintaan masing-masing produk dipengaruhi secara positif oleh jumlah anggota yang bersama-sama melakukan usaha untuk promosi kedua produk yang berbeda tersebut secara bersama-sama.

Pada model ini diberikan asumsi bahwa kapasitas produksi yang bersifat terbatas tetapi dengan ketersediaan bahan baku yang memadai, produksi terjadi terus-menerus tanpa stock out, permintaan yang dilakukan oleh konsumen merupakan penjualan produk yang dilakukan perusahaan, permintaan dan kapasitas produksi setiap saat dipengaruhi inisiatif tim sales (dalam hal ini dimodelkan dengan jumlah sales dalam tim tersebut). Setiap orang dalam tim sales dianggap memiliki skill atau kemampuan mempengaruhi yang sama untuk mendatangkan konsumen, keandalan mesin produksi dianggap sama, model pengendalian persediaan produk jenis 1 hanya dipengaruhi oleh persediaan produk jenis 1 dan tidak dipengaruhi persediaan produk jenis 2 pada tingkat kapasitas produksi masing-masing terbatas, begitu pula se- baliknya, serta permintaan ke dua jenis produk dipengaruhi oleh inisiatif tim sales secara bersama. Dalam horison waktu penelitian, suku bunga dan inflasi dari mata uang yang mempengaruhi pendapatan laba bersih bernilai tetap, dan pada penjualan produk tidak berlaku discount price.

\section{Metode Penelitian}

Penurunan model sistem dinamik yang dilakukan sama dengan yang telah dilakukan Sana [6, 7]. Dalam hal ini pengendalian persediaan dipengaruhi oleh tingkat persediaan produk dan tingkat kapasitas produksi pada waktu $t$. Tingkat persediaan pada waktu $t$ dari masing-masing produk tersebut tidak diperbolehkan bernilai negatif atau nol dan juga tidak diperbolehkan melebihi dari jumlah kapasitas produksi. Selain itu, jumlah dari kapasitas produksi masing-masing produk tidak diperbolehkan melebihi kapasitas maksimum produksi sehingga;

$0<X \leq C_{x} \leq C_{x \max }$

dan

$0<Y \leq C_{y} \leq C_{y \max }$

Tingkat persediaan dipengaruhi oleh tingkat produksi dan tingkat permintaan masing-masing produk. Misalkan untuk tingkat produksi, jumlah persediaan produk jenis 1 dinotasikan dengan $X$ dan produk jenis 2 dinotasikan dengan $Y$. Model yang umum digunakan untuk menggambarkan produksi adalah model logistik, yang berbentuk;

$P_{x}=r_{x} X\left(1-\frac{X}{C_{x}}\right)$

$P_{y}=r_{y} Y\left(1-\frac{Y}{C_{y}}\right)$

dimana $r_{x}$ dan $r_{y}$ merupakan laju pertumbuhan potensial masing-masing produk. Seperti halnya untuk tingkat produksi, pada tingkat permintaan juga diasumsikan mengikuti persamaan logistik. Jumlah persediaan masing-masing produk untuk tingkat permintaan dibatasi oleh pengaruh inisiatif tim sales bersama. Hal tersebut mengakibatkan tingkat permintaan pada akhirnya mengalami pertumbuhan yang terbatas dengan pengaruh proporsional antara suatu produk dan jumlah inisiatif tim sales bersama. Jumlah agen dari inisiatif tim sales bersama untuk kedua produk dinotasikan dengan $N$. Sehingga tingkat permintaan untuk produk jenis 1 dan 2 menjadi

$D_{x}=\tau_{x} X-\tau_{x} X \frac{1}{1+N}$
$D_{y}=\tau_{y} Y-\tau_{y} Y \frac{1}{1+N}$

Sana [6,7] memperlihatkan bahwa terdapat suatu kondisi tertentu mengenai permintaan untuk 
masing-masing produk terkait inisiatif tim sales bersama. Saat tingkat permintaan dipengaruhi oleh inisiatif tim sales bersama maka untuk produk jenis $1, \frac{\partial D_{X}}{\partial N}=\frac{\tau_{X} X}{(1+N)^{2}}$ akan bernilai positif untuk setiap $X \in(0, \infty)$ dan $\lim _{N \rightarrow \infty} D_{x} \rightarrow \tau_{x} X$ sehingga $D_{x} \in$ $\left[0, \tau_{x} X\right]$. Hal tersebut berarti tingkat permintaan produk jenis 1 pada waktu $t$ dengan kondisi pengaruh inisiatif tim sales yang tidak terbatas masih menghasilkan permintaan yang terbatas. Hal serupa berlaku untuk produk 2. Mengingat bahwa tingkat persediaan produk merupakan selisih tingkat produksi dan tingkat permintaan produk, maka persamaan diferensial untuk tingkat persediaan yang tersedia pada waktu $t$ untuk produk jenis 1 dan 2 berturut-turut adalah;

$\dot{X}=P_{x}-D_{x}=r_{x} X\left(1-\frac{X}{C_{x}}\right)-\tau_{x} X\left(1-\frac{1}{1+N}\right)$
$\dot{Y}=P_{y}-D_{y}=r_{y} Y\left(1-\frac{Y}{C_{y}}\right)-\tau_{y} Y\left(1-\frac{1}{1+N}\right)$.

Kapasitas produksi adalah jumlah produk yang dapat dihasilkan oleh perusahaan dalam suatu periode tertentu dengan menggunakan sumber daya saat ini. Tingkat kapasitas produksi untuk produk jenis 1 dan produk jenis 2 dipengaruhi oleh pertumbuhan dan peluruhan jumlah bahan baku setiap produk. Misalkan untuk pertumbuhan jumlah bahan baku, jumlah kapasitas produksi produk jenis 1 dinotasikan dengan $C_{x}$ dan produk jenis 2 dinotasikan dengan $C_{y}$. Sebagaimana persediaan, kapasitas produksi juga diasumsikan mengikuti pertumbuhan logistik, sehingga diperoleh persamaan pertumbuhan kapasitas produksi untuk kedua produk adalah:

$\dot{C}_{x}=q_{x} C_{x}\left(1-\frac{C_{x}}{C_{x \max }}\right)$

$\dot{C}_{y}=q_{y} C_{y}\left(1-\frac{C_{y}}{C_{y \max }}\right)$.

dengan $q_{x}$ dan $q_{y}$ adalah koefisien laju pertumbuhan kapasitas produksi. Pada tingkat kapasitas produksi, peluruhan yang terjadi pada bahan baku terjadi akibat dari kegiatan inisiatif tim sales. Peluruhan terjadi akibat pengaruh koefisien laju peluruhan kapasitas produksi yang dinotasikan $\gamma_{x}$ dan $\gamma_{y}$, inisiatif tim sales bersama dinotasikan dengan $N$, serta kapasitas produksi yang tersedia untuk masing-masing produk yang dinotasikan $C_{x}$ dan $C_{y}$. Persamaan diferensial yang terbentuk pada tingkat kapasitas produksi untuk produk jenis 1 dan jenis 2 dirumuskan sebagai;

$\dot{C}_{x}=q_{x} C_{x}\left(1-\frac{C_{x}}{C_{x \max }}\right)-\gamma_{x} N C_{x}$
$\dot{C}_{y}=q_{y} C_{y}\left(1-\frac{C_{y}}{C_{y \max }}\right)-\gamma_{y} N C_{y}$

dimana $q_{x}, q_{y}, \gamma_{x}$ dan $\gamma_{y}$ merupakan koefisien positif. Pada model pengendalian persediaan yang dibahas, kapasitas produksi merupakan variabel keadaan sementara inisiatif tim sales sebagai variabel kontrol. Meninjau persamaan (7), (8), (11) serta (12) maka sistem dinamik untuk model pengendalian persediaan dua produk berbeda pada kapasitas produksi terbatas serta inisiatif tim sales bersama dari waktu ke waktu diberikan oleh;

$$
\begin{aligned}
& \dot{X}=r_{x} X\left(1-\frac{X}{C_{x}}\right)-\tau_{x} X\left(1-\frac{1}{1+N}\right)=F_{1}\left(X, C_{x}\right) \\
& \dot{Y}=r_{y} Y\left(1-\frac{Y}{C_{y}}\right)-\tau_{y} Y\left(1-\frac{1}{1+N}\right)=F_{2}\left(Y, C_{y}\right) \\
& \dot{C_{x}}=q_{x} C_{x}\left(1-\frac{C_{x}}{C_{x \max }}\right)-\gamma_{x} N C_{x}=F_{3}\left(C_{x}\right) \\
& \dot{C_{y}}=q_{y} C_{y}\left(1-\frac{C_{y}}{C_{y \max }}\right)-\gamma_{y} N C_{y}=F_{4}\left(C_{y}\right)
\end{aligned}
$$

dengan $X(0)=X^{*}, Y(0)=Y^{*}, \quad C_{x}(0)=C_{x}{ }^{*}$, dan $C_{y}(0)=C_{y}{ }^{*}$. Fungsi-fungsi $F_{1}$ dan $F_{2}$ merupakan fungsi persediaan produk yang didapat dari selisih tingkat produksi dan tingkat permintaan untuk masing-masing produk dengan inisiatif tim sales bersama pada waktu $t$. Sementara $F_{3}$ dan $F_{4}$ merupakan fungsi kapasitas produksi dari selisih hasil pengaruh pertumbuhan dan peluruhan bahan baku serta inisiatif tim sales bersama untuk masingmasing produk pada waktu $t$.

\section{Analisis Model}

Setelah sistem dinamik untuk model persediaan terbentuk, selanjutnya dilakukan analisis kestabilan untuk mengetahui perilaku model persediaan tersebut. Steady state (titik tetap) dari suatu sistem dikatakan stabil jika semua nilai eigen yang diperoleh pada kondisi steady-state tersebut merupakan nilai eigen yang negatif (Wiggins [9]). Perhatikan Tabel 1, agar persediaan kedua produk selalu ada, maka titik tetap nomor 4 harus stabil. Tabel 1 juga memperlihatkan beberapa kondisi yang mungkin terjadi pada sistem setelah dilakukan analisis kestabilannya.

Sebagai catatan kondisi pada Tabel 1 akan terpenuhi jika laju permintaan masing-masing produk jenis $1\left(\tau_{x}\right)$ dan $2\left(\tau_{y}\right)$ lebih kecil dibandingkan laju pertumbuhan potensial produksi masing-masing produk $\left(r_{x}, r_{y}\right)$ dan laju pertumbuhan kapasitas produksi masing-masing produk jenis $1\left(q_{x}\right)$ dan jenis $2\left(q_{y}\right)$ lebih besar dibandingkan laju peluruhan kapasitas produksi masing-masing produk $\left(\gamma_{x}, \gamma_{y}\right)$. Jika syarat ini dipenuhi, maka keadaan ketika tersedianya produk jenis 1 dan produk jenis 2 dengan kapasitas produksi masing-masing tersedia pada sistem merupakan keadaan yang stabil. Keadaan stabil tersebut mengandung arti yaitu keadaan dimana kondisi keseimbangan pasar antara tingkat persediaan dan penawaran akan tercapai. 
Tabel 1. Tabel analisis kestabilan

\begin{tabular}{|c|c|c|c|}
\hline No & $\begin{array}{l}\text { Titik tetap } \\
\left(X, Y, C_{x}, C_{y}\right)\end{array}$ & Nilai Eigen & Titik kestabilan \\
\hline 1 & $\begin{array}{l}\text { Kondisi ketika tidak } \\
\text { tersedianya produk } \\
\text { jenis } 1 \text { dan jenis } 2 \\
\left(0,0, C_{x}{ }^{*}, C_{y}{ }^{*}\right)\end{array}$ & $\begin{array}{c}\lambda_{1}=r_{x}\left(1-\frac{\tau_{x} N}{r_{x}(1+N)}\right) \\
\lambda_{2}=r_{y}\left(1-\frac{\tau_{y} N}{r_{y}(1+N)}\right) \\
\lambda_{3}=-q_{x}\left(1-\frac{\gamma_{x} N}{q_{x}}\right), \lambda_{4}=-q_{y}\left(1-\frac{\gamma_{y} N}{q_{y}}\right)\end{array}$ & $\begin{array}{l}\text { Tidak stabil } \\
\text { (2 nilai eigen positif dan } 2 \\
\text { nilai eigen negatif) }\end{array}$ \\
\hline 2 & $\begin{array}{l}\text { Kondisi ketika tidak } \\
\text { tersedianya produk } \\
\text { jenis1 }\left(0, Y^{*}, C_{x}{ }^{*}, C_{y}{ }^{*}\right)\end{array}$ & $\begin{array}{c}\lambda_{1}=r_{x}\left(1-\frac{\tau_{x} N}{r_{x}(1+N)}\right), \lambda_{5}=-r_{y}\left(1-\frac{\tau_{y} N}{r_{y}(1+N)}\right) \\
\lambda_{3}=-q_{x}\left(1-\frac{\gamma_{x} N}{q_{x}}\right), \lambda_{4}=-q_{y}\left(1-\frac{\gamma_{y} N}{q_{y}}\right)\end{array}$ & $\begin{array}{l}\text { Tidak stabil } \\
\text { (terdapat satu nilai eigen } \\
\text { positif) }\end{array}$ \\
\hline 3 & $\begin{array}{l}\text { Kondisi ketika tidak } \\
\text { tersedianya produk } \\
\text { jenis } 2\left(X^{*}, 0, C_{x}{ }^{*}, C_{y}{ }^{*}\right)\end{array}$ & $\begin{array}{c}\lambda_{6}=-r_{x}\left(1-\frac{\tau_{x} N}{r_{x}(1+N)}\right), \lambda_{2}=r_{y}\left(1-\frac{\tau_{y} N}{r_{y}(1+N)}\right), \\
\lambda_{3}=-q_{x}\left(1-\frac{\gamma_{x} N}{q_{x}}\right), \lambda_{4}=-q_{y}\left(1-\frac{\gamma_{y} N}{q_{y}}\right) .\end{array}$ & $\begin{array}{l}\text { Tidak stabil } \\
\text { (terdapat satu nilai eigen } \\
\text { positif) }\end{array}$ \\
\hline 4 & $\begin{array}{l}\text { Kondisi ketika } \\
\text { tersedianya produk } \\
\text { jenis } 1 \text { dan jenis } 2 \\
\left(X^{*}, Y^{*}, C_{x}{ }^{*}, C_{y}{ }^{*}\right)\end{array}$ & $\begin{array}{c}\lambda_{6}=-r_{x}\left(1-\frac{\tau_{x} N}{r_{x}(1+N)}\right) \\
\lambda_{5}=-r_{y}\left(1-\frac{\tau_{y} N}{r_{y}(1+N)}\right) \\
\lambda_{3}=-q_{x}\left(1-\frac{\gamma_{x} N}{q_{x}}\right), \lambda_{4}=-q_{y}\left(1-\frac{\gamma_{y} N}{q_{y}}\right)\end{array}$ & $\begin{array}{l}\text { Stabil } \\
\text { (mempunyai } 4 \text { nilai eigen } \\
\text { yg negatif) }\end{array}$ \\
\hline
\end{tabular}

dengan:

$X^{*}=C_{x \max }\left(1-\frac{\gamma_{x} N}{q_{x}}\right)\left(1-\frac{\tau_{x} N}{r_{x}(1+N)}\right)$,

$Y^{*}=C_{y \max }\left(1-\frac{\gamma_{y} N}{q_{y}}\right)\left(1-\frac{\tau_{y} N}{r_{y}(1+N)}\right)$,

$C_{x}^{*}=C_{x \max }\left(1-\frac{\gamma_{x} N}{q_{x}}\right)$

$C_{y}{ }^{*}=C_{y \max }\left(1-\frac{\gamma_{y} N}{q_{y}}\right)$

Setelah dilakukan analisis kestabilan, selanjutnya dicari nilai $N$ yang optimal untuk memaksimalkan fungsi laba bersih dari sistem pada model persediaan yang dibentuk dalam paper ini. Fungsi laba bersih yang dibentuk merupakan pengembangan fungsi laba bersih dalam penelitian (Sana [6]). Menurut (Pontryagin [10]) total laba bersih pada 2 produk berbeda adalah

$J=\int_{0}^{\infty}\left(\left(w_{x}-w_{0 x}\right) \frac{\tau_{x} N X}{1+N}+\left(w_{y}-w_{0 y}\right) \frac{\tau_{y} N Y}{1+N}-w_{1} N-\right.$

$\left.w_{2 x} C_{x}-w_{2 y} C_{y}\right) e^{-\delta t} d t$

Sehinga masalah optimisasi menjadi

$$
\max _{0<N<N_{\max }} J
$$

dengan persamaan kendala

$$
\begin{aligned}
& \dot{X}=r_{x} X\left(1-\frac{X}{C_{x}}\right)-\tau_{x} X\left(1-\frac{1}{1+N}\right)=F_{1}\left(X, C_{x}\right) \\
& \dot{Y}=r_{y} Y\left(1-\frac{Y}{C_{y}}\right)-\tau_{y} Y\left(1-\frac{1}{1+N}\right)=F_{2}\left(X, C_{y}\right) \\
& \dot{C_{x}}=q_{x} C_{x}\left(1-\frac{C_{x}}{C_{x \max }}\right)-\gamma_{x} N C_{x}=F_{3}\left(C_{x}\right),
\end{aligned}
$$

$\dot{C}_{y}=q_{y} C_{y}\left(1-\frac{C_{y}}{C_{y \max }}\right)-\gamma_{y} N C_{y}=F_{4}\left(C_{y}\right)$

dan dengan kondisi awal $X(0)=X_{0}>0, Y(0)=$ $Y_{0}>0, C(0)=C_{0}>0$ serta $N(0)=N_{0} \geq 0$. Lampiran 1 memperlihatkan bahwa nilai optimal $N$ adalah $N^{*}$ yang memenuhi persamaan (L.1). Nilai dari $N=N^{*}$ merupakan jumlah sales optimal untuk memaksimumkan laba bersih pada model pengendalian persediaan dengan kontrol inisiatif tim sales bersama dari dua produk berbeda. Solusi optimal untuk $X, Y, C_{x}$ dan $C_{y}$ diberikan oleh (17)-(20) untuk $N=N^{*}$.

\section{Hasil dan Pembahasan}

Sebagai ilustrasi diberikan contoh berikut dengan nilai parameter pada simulasi numerik diambil dari (Sana, [5]) dimana $r_{x}=r_{y}=8 ; \tau_{x}=0,8 ; \tau_{y}=$ 0,6; $C_{x \max }=700$ unit; $C_{y \max }=600$ unit; $w_{x}=$ $\$ 50 ; w_{y}=\$ 60 ; w_{0 x}=\$ 25 ; w_{0 y}=\$ 30 ; w_{1}=\$ 100 ;$ $w_{2 x}=w_{2 y}=\$ 0,5 ; \delta=0,05$. Sementara untuk nilai parameter untuk koefisien positif pada kapasitas produksi diambil dari (Sana [5]) dimana $q_{x}=q_{y}=$ 2 dan $\gamma_{x}=\gamma_{y}=0,001$. Dalam kasus tersebut ditinjau agar tidak terjadi stock out, sehingga didapat solusi kontrol optimal inisiatif tim sales bersama $N^{*}$ adalah 184,4963393 atau 185 orang. Selain itu didapat kondisi keadaaan (state) yang optimal, yaitu untuk tingkat persediaan untuk produk jenis 1 adalah sebanyak 572,2262077 atau 573 unit pada kapasitas produksi yang tersedia 
sebanyak 635,4262812 atau 636 unit dengan kapasitas produksi maksimum sebanyak 700 unit, sementara untuk tingkat persediaan untuk produk jenis 2 adalah sebanyak 504,0224795 atau 505 unit pada kapasitas produksi yang tersedia sebanyak 544,651 atau 545 unit dengan kapasitas produksi maksimum sebanyak 600 unit. Pendapatan laba bersih maksimum yang didapat pada kondisi-kondisi optimal adalah 1349,016. Dengan kasus tersebut, didapat grafik pada model dari waktu ke waktu. Jumlah persediaan produk dan kapasitas produksi masing-masing produk tersebut memperhatikan perolehan laba bersih maksimum pada sistem model pengendalian persediaan yang dibentuk dalam penelitian ini.

Phase Potrait pada Gambar 1 dan Gambar 2 memperlihatkan bahwa trayektori menuju ke suatu titik. Titik tersebut merupakan titik kestabilan pada $(572,226 ; 635,426)$ dan $(504,0225 ; 544,651)$. Nilai eigen untuk Gambar 1 adalah -7,204 dan -1,815 serta Gambar 2 adalah -7,403 dan -1,815. Nilai eigen tersebut menunjukkan bahwa titik kestabilan dalam kondisi stabil (Stable Node). Titik tersebut juga menggambarkan bahwa tingkat persediaan produk dan kapasitas produksi dapat memenuhi permintaan pasar karena dalam kondisi stabil.

Perilaku model dalam simulasi kasus dalam penelitian ini dapat dilihat dari beberapa grafik terhadap waktu yang dibentuk. Grafik yang dibentuk meliputi grafik tingkat persediaan produk, tingkat produksi, tingkat permintaan produk, dan tingkat kapasitas produksi dari produk jenis 1 dan produk jenis 2. Grafik yang dibentuk membandingkan antara keadaan dengan dan tanpa kontrol optimal. Grafik tingkat persediaan produk terhadap waktu dengan dan tanpa kontrol optimal dapat dilihat pada Gambar 3 dan Gambar 4.

Grafik pada Gambar 3 sampai dengan Gambar 6 menunjukkan pengaruh kontrol yang dilakukan oleh inisiatif tim sales bersama dengan memperhatikan laba bersih maksimum dari waktu ke waktunya. Pengaruh yang terjadi ketika adanya inisiatif tim sales dari waktu ke waktunya yaitu jumlah persediaan dan kapasitas produksi untuk produk jenis 1 serta produk jenis 2 mengalami penurunan. Hal tersebut berbeda dengan ketika tidak adanya inisiatif tim sales dari waktu ke waktunya yaitu menunjukkan peningkatan jumlah persediaan dan kapasitas produksi yang dikarenakan tidak adanya aktifitas penjualan dalam sistem. Tidak adanya aktifitas penjualan oleh inisiatif tim sales berdampak pada sistem yang akhirnya terjadi penumpukan produk pada perusahaan. Grafik tingkat produksi terhadap waktu dengan dan tanpa kontrol oleh inisiatif tim sales dapat dilihat pada Gambar 7 dan Gambar 8.

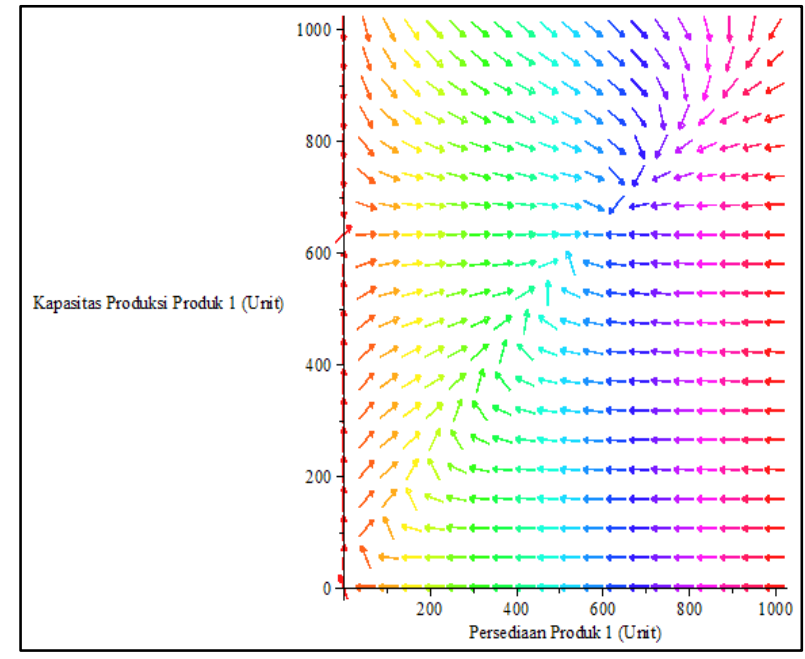

Gambar 1. Phase potrait persediaan produk terhadap kapasitas produksi produk jenis 1

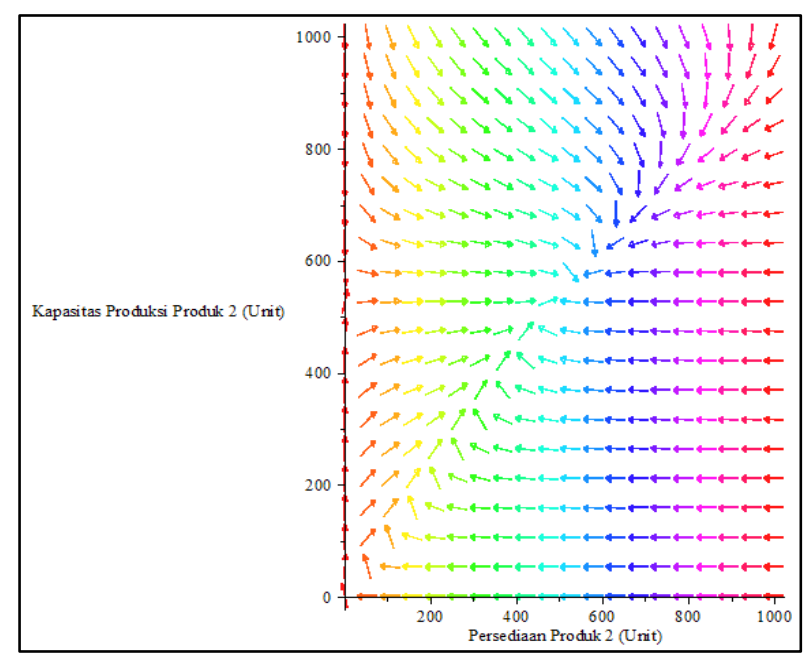

Gambar 2. Phase potrait persediaan produk terhadap kapasitas produksi produk jenis 2

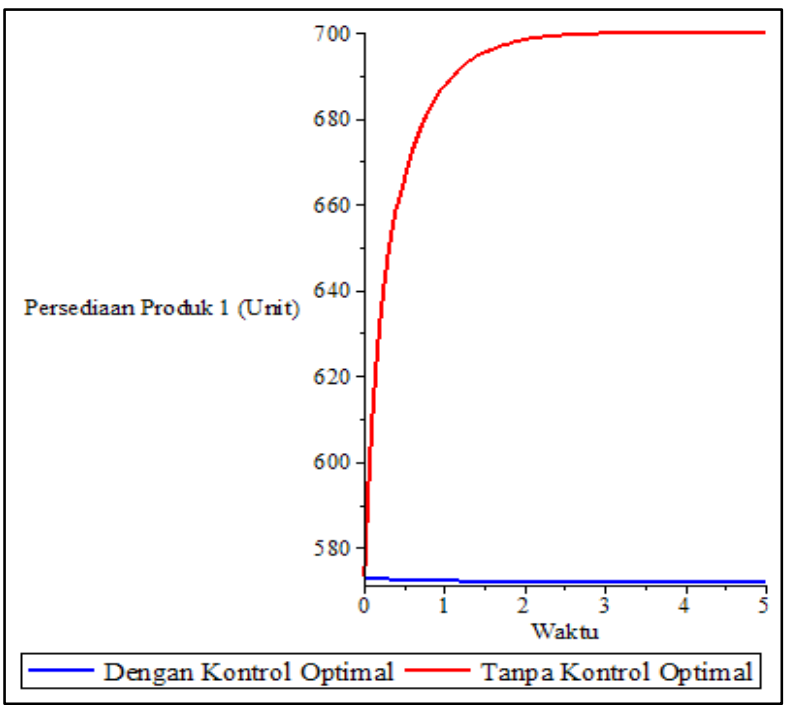

Gambar 3. Grafik tingkat persediaan produk 1 


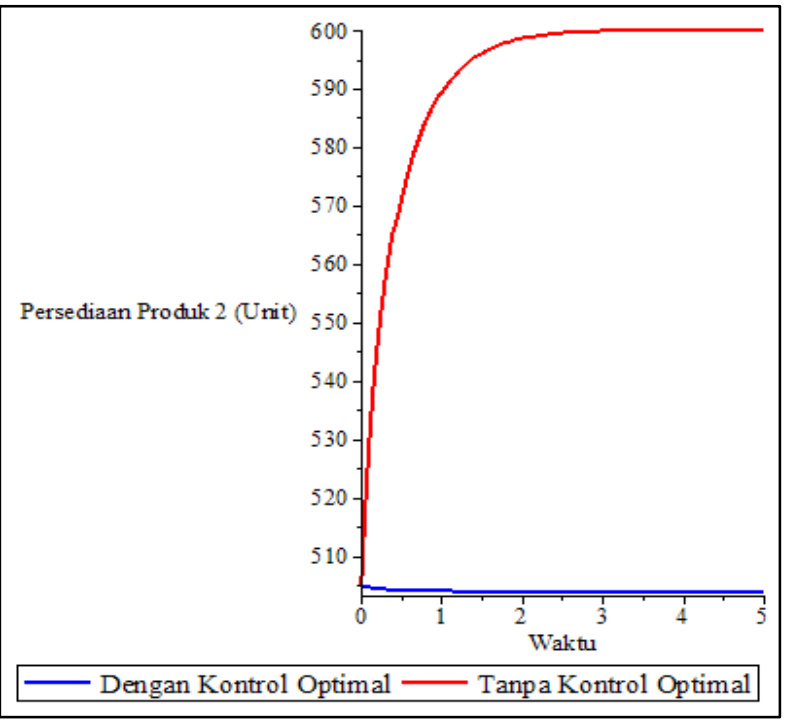

Gambar 4. Grafik tingkat persediaan produk 2

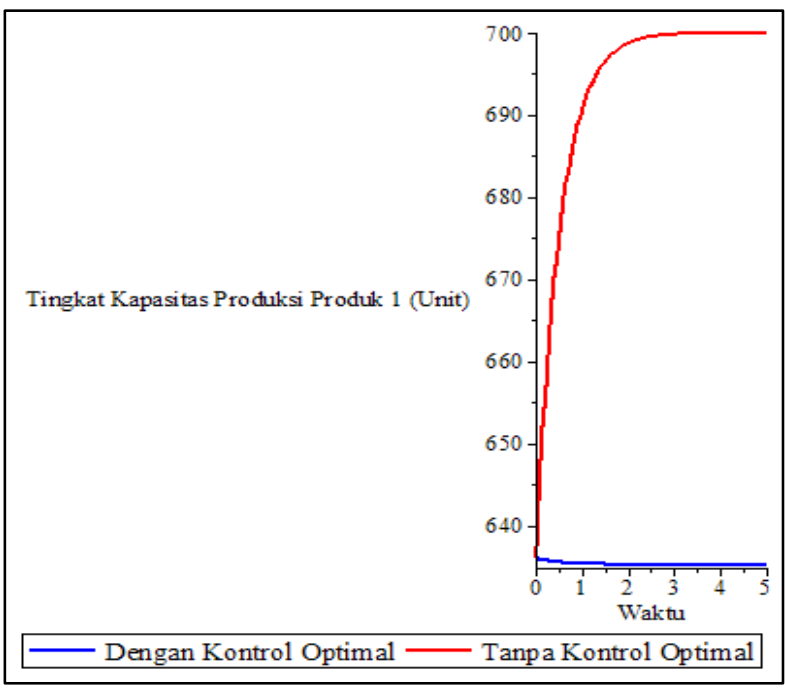

Gambar 5. Grafik tingkat kapasitas produksi produk 1

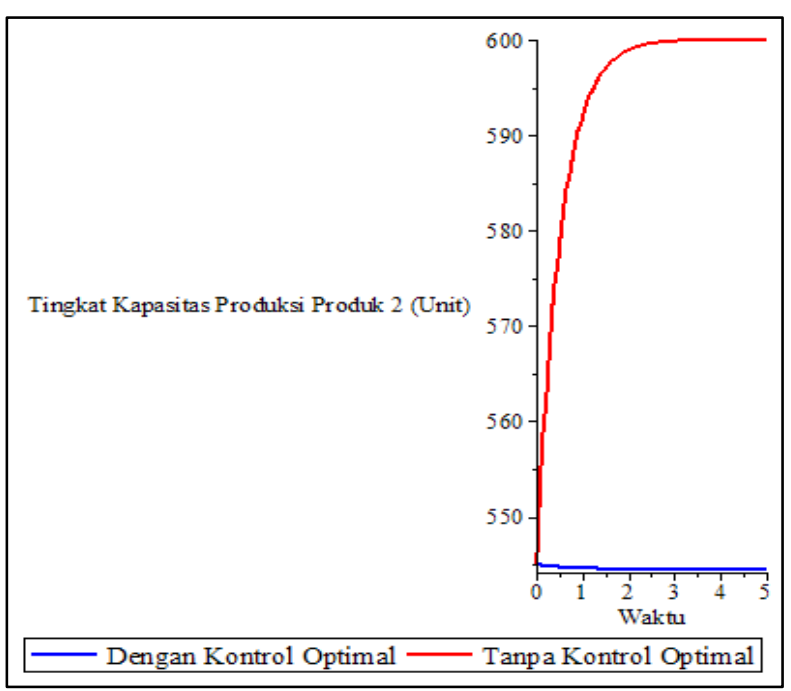

Gambar 6. Grafik tingkat kapasitas produksi produk 2

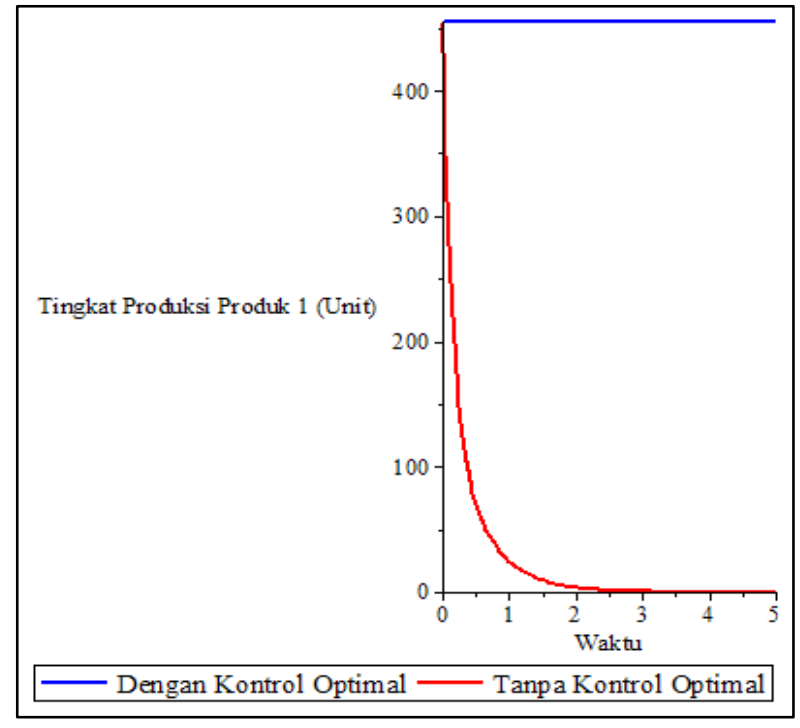

Gambar 7. Grafik tingkat produksi produk 1

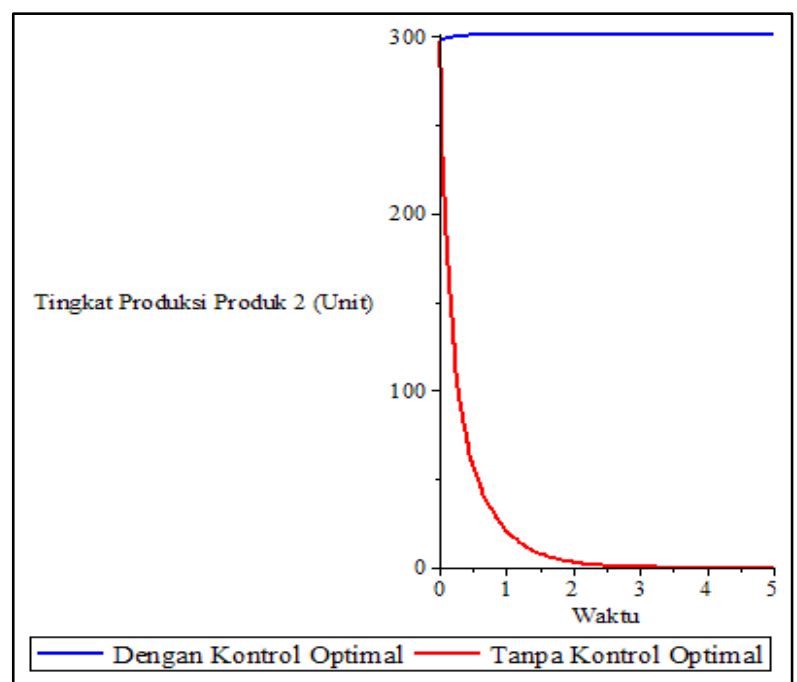

Gambar 8. Grafik tingkat produksi produk 2

\section{Analisis Sensitivitas}

Untuk melihat perilaku model terhadap perubahan parameter-parameter model dilakukan analisis sensitivitas seperti pada gambar berikut. Nilai paramemeter mengacu pada (Sana [6]). Gambar grafik 9 dan 10 menunjukkan bahwa semakin meningkat laju pertumbuhan potensial maka jumlah inisiatif tim sales menurun berbeda hal nya dengan produk jenis 2 yang membuat jumlah inisiatif tim sales meningkat.

Gambar grafik 11 sampai dengan Gambar grafik 16 menunjukkan bahwa semakin meningkat koefisien laju permintaan produksi, kapasitas maksimum produksi dan pendapatan penjualan produk maka semakin meningkat juga jumlah inisiatif tim sales yang terlibat untuk produk jenis 1 dan jenis 2 . 


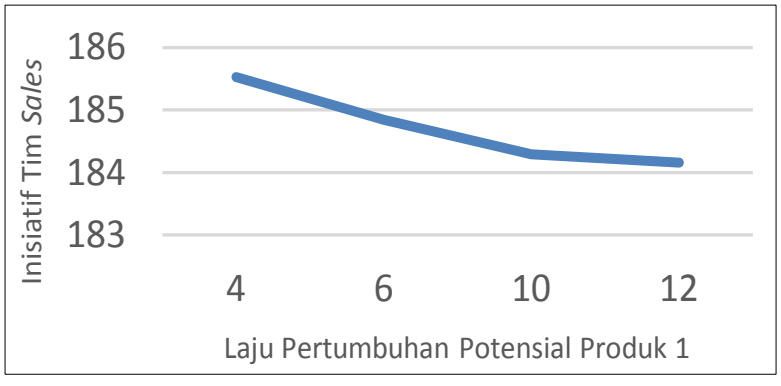

Gambar 9. Grafik analisis sensitivitas koefisien laju pertumbuhan potensial produksi terhadap inisatif tim sales bersama produk jenis 1

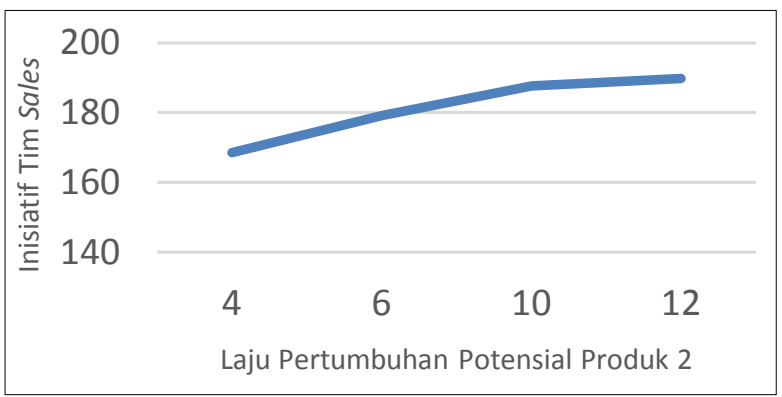

Gambar 10. Grafik analisis sensitivitas koefisien laju pertumbuhan potensial produksi terhadap inisatif tim sales bersama produk jenis 2

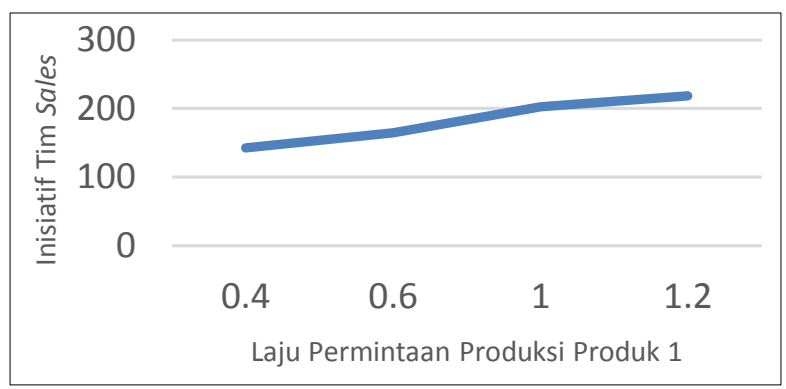

Gambar 11. Grafik analisis sensitivitas koefisien laju permintaan produksi terhadap inisatif tim sales bersama produk jenis 1

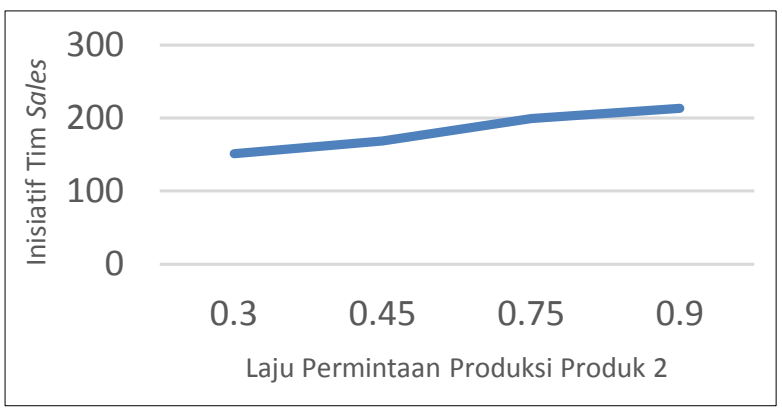

Gambar 12. Grafik analisis sensitivitas koefisien laju permintaan produksi terhadap inisatif tim sales bersama produk jenis 2

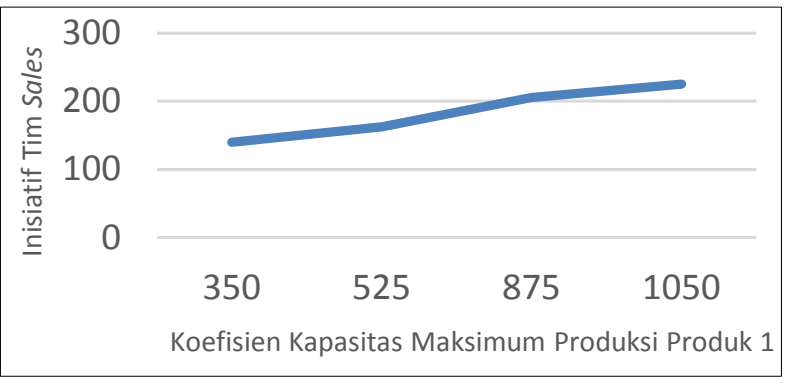

Gambar 13. Grafik analisis sensitivitas koefisien kapasitas maksimum produksi terhadap inisiatif tim sales bersama produk jenis 1

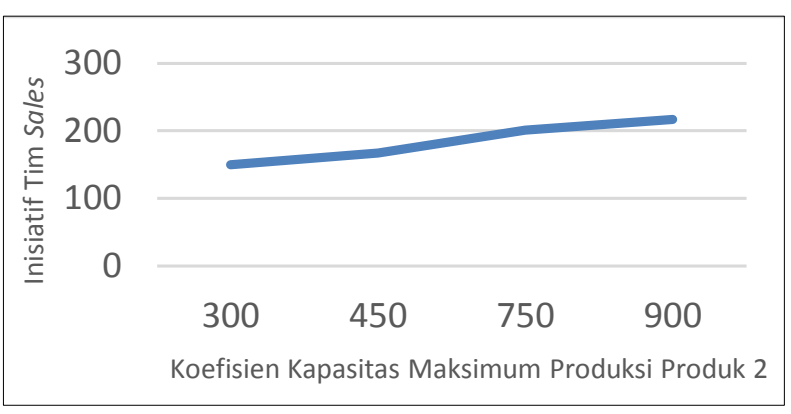

Gambar 14. Grafik analisis sensitivitas koefisien kapasitas maksimum produksi terhadap inisiatif tim sales bersama produk jenis 2 .

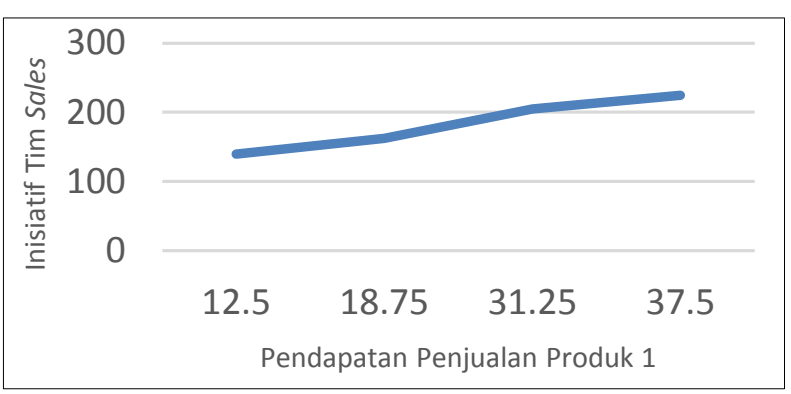

Gambar 15. Grafik analisis sensitivitas pendapatan penjualan produk terhadap inisiatif tim sales bersama produk jenis 1

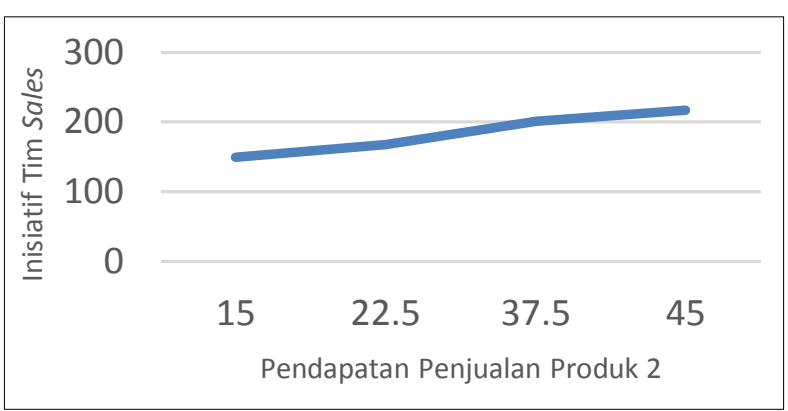

Gambar 16. Grafik analisis sensitivitas pendapatan penjualan produk terhadap inisiatif tim sales bersama produk jenis 2 


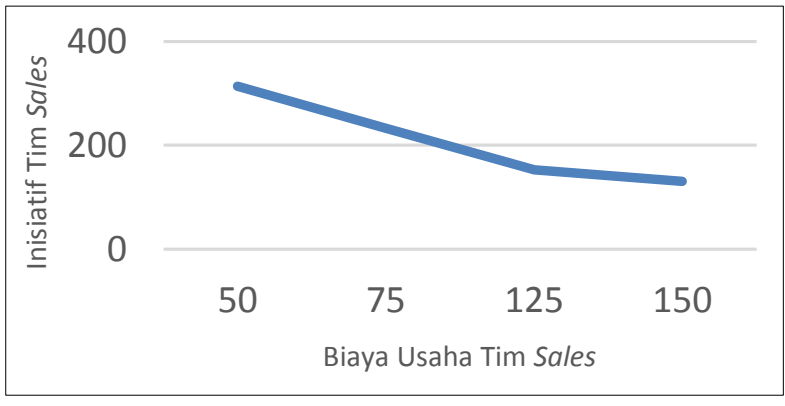

Gambar 17. Grafik analisis sensitivitas biaya usaha tim sales bersama terhadap inisiatif tim sales bersama

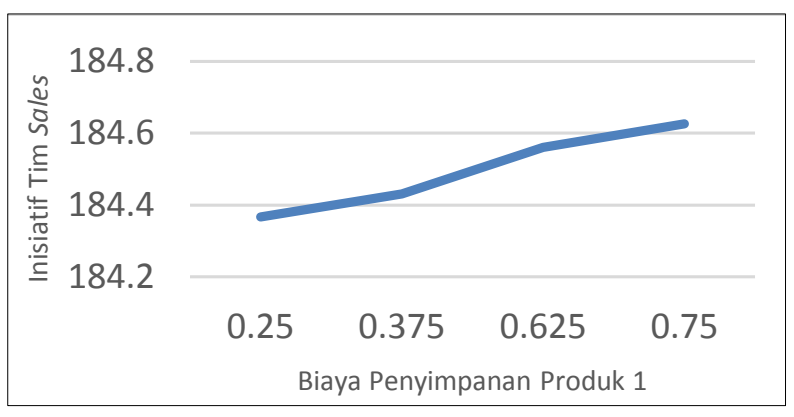

Gambar 18. Grafik analisis sensitivitas biaya penyimpanan terhadap inisiatif tim sales bersama produk jenis 1

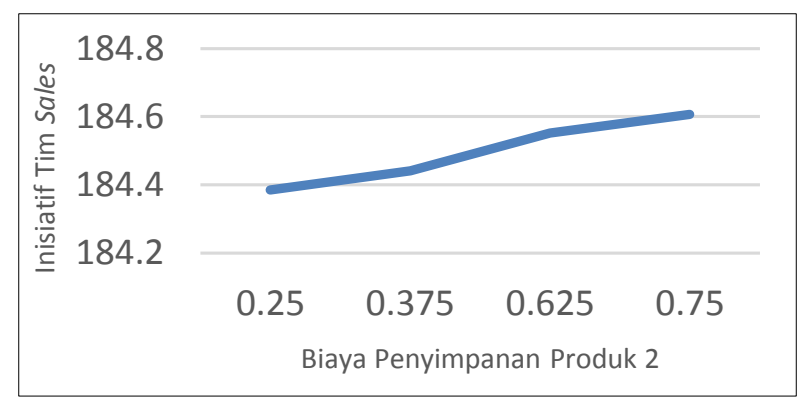

Gambar 19. Grafik analisis sensitivitas biaya penyimpanan terhadap inisiatif tim sales bersama produk jenis 2

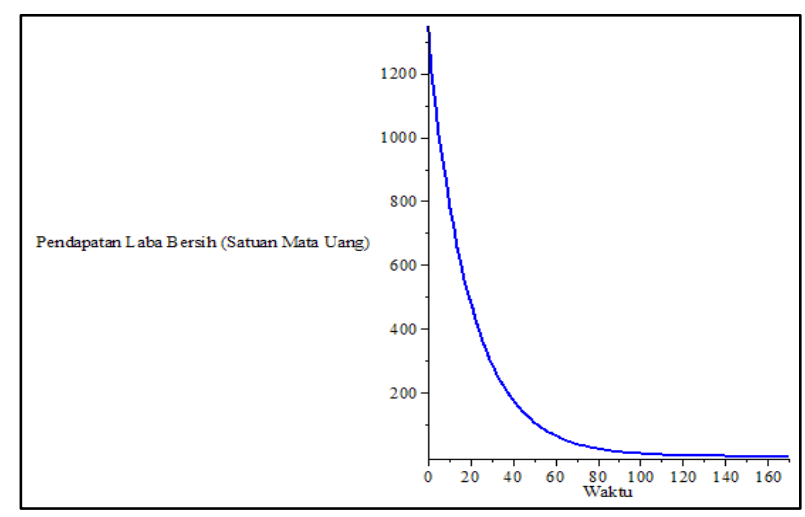

Gambar 20. Grafik pendapatan laba bersih

Gambar 17 menunjukkan bahwa semakin tinggi biaya yang harus dikeluarkan untuk tim sales mengakibatkan semakin menurunnya jumlah agents yang diperlukan. Gambar grafik 18 dan 19 menunjukkan bahwa ketika meningkatnya pendapatan penjualan produk meningkat serta biaya penyimpanan maka semakin meningkat jumlah inisiatif tim sales yang terlibat.

Gambar 20 merupakan gambar grafik untuk pendapatan laba bersih dengan meninjau nilai mata uang pada sistem yang dibentuk terhadap waktu ke waktu. Pendapatan laba bersih maksimum yang didapat pada kondisi-kondisi optimal adalah 1349,016 . Salah satu pengembangan yang dapat terjadi adalah jika terjadi perubahan komposisi kapasitas produksi maksimum dengan tetap mempertahankan jumlah kapasitas maksimum produksi pada sistem yakni 1300 unit. Setelah melakukan analisis sensitivitas dihasilkan kecenderungan pendapatan laba bersih yang lebih besar ketika banyaknya kapasitas maksimum produksi produk jenis 1 lebih besar daripada kapasitas maksimum produksi produk jenis 2 . Selain hal tersebut, ketika komposisi kapasitas maksimum produksi berubah dengan mempertahankan jumlah kapasitas maksimum produksi kedua produk, menghasilkan persediaan produk jenis 1 lebih besar daripada persediaan produk jenis 2 .

\section{Simpulan}

Dalam paper ini telah diperoleh model pengendalian persediaan dengan dua produk berbeda pada kapasitas produksi terbatas serta inisiatif tim sales bersama, dengan menggunakan pendekatan sistem dinamik. Hasil yang diperoleh untuk masing-masing produk yaitu, tingkat persediaan produk merupakan selisih dari tingkat produksi yang dibatasi oleh kapasitas produksi, serta tingkat permintaan yang dibatasi oleh inisiatif tim sales bersama. Selanjutnya setelah mendapatkan model matematika didapatkan juga syarat perlu yang harus dipenuhi agar produk jenis 1 dan 2 pada sistem dalam keadaan stabil, yaitu ketika laju permintaan masing-masing produk lebih kecil dibandingkan laju pertumbuhan potensial produksi masing-masing produk dan laju pertumbuhan kapasitas produksi masing-masing produk lebih besar dibandingkan laju peluruhan kapasitas produksi masing-masing produk, hal ini mengakibatkan keadaan persediaan serta kapasitas produksi produk jenis 1 dan 2 akan tersedia. Selain itu, diperoleh perilaku dinamik setiap kompartemennya dari waktu ke waktu, diperoleh juga kondisi optimal dengan memaksimumkan laba bersih serta dipengaruhi suku bunga dan inflasi dari mata uang yang pada akhirnya didapat kebijakan pengendalian persediaan produk yaitu pendapatan laba bersih akan lebih besar ketika banyaknya kapasitas maksimum produksi produk jenis 1 lebih besar daripada kapasitas maksimum produksi produk 
jenis 2. Analisis sensitivitas memperlihatkan bahwa jika permintaan produksi semakin meningkat, maka kapasitas produksi dan kapasitas maksimum produksi akan meningkat. Ketika pendapatan penjualan produk semakin besar dan biaya penyimpanan meningkat, maka inisiatif tim sales pun akan semakin besar. Selain itu, ketika komposisi kappasitas maksimum produksi berubah dengan mempertahankan jumlah kapasitas maksimum produksi kedua produk, menghasilkan persediaan produk jenis 1 lebih besar daripada persediaan produk jenis 2 .

\section{Ucapan Terima Kasih}

Sebagian dari penelitian ini dibiayai oleh Kementerian Riset, Teknologi, dan Pendidikan Tinggi melalui skema Riset Insentif Sistem Inovasi Nasional tahun 2015.

\section{Daftar Pustaka}

1. Rangkuti, A., 7 Model Riset Operasi \& Aplikasinya (Cetakan ke-1), Surabaya: Brilian International, 2013.

2. Ghosh, S.K. and Chaudhuri, K.S., An Order Level Inventory Model for a Deteriorating Item with Two Levels of Storage Stock-Dependent Demand, Far East Journal of Applied Mathematics, 15, 2004, pp. 63-77.

3. Datta, T.K. and Pal, A.K., Deterministic Inventory Systems for Deteriorating Items with Inventory Level Dependent Demand Rate and Shortages, Opsearch, 27, 1990, pp. 213-224.

4. Baker, R.C. and Urban, T.L., Single-Period Inventory Dependent Demand Models, Omega, 16, 1988, pp. 605-615.

5. Sana, S.S., Sales Team's Initiatives and Stock Sensitive Demand-A Production Control Policy. Economic Modelling, 31, 2013, pp. 783-788.

6. Sana, S.S., An EOQ Model of Homogeneous Products while Demand is Salesmen's Initiatives and Stock Sensitive. Computers and Mathematics with Applications, 62, 2011, pp. 577-578.

7. Sana, S.S., An EOQ Model for Salesmen's Initiatives, Stock and Price Sensitive Demand of Similar Products-A Dynamical System. Applied Mathematics and Computation, 218, 2011, pp. 3277-3288.

8. Sana, S.S., The EOQ Model-A Dynamical System. Applied Mathematics and Computation 2(18), 2012, pp. 8736-8749.

9. Wiggins, S., Introduction to Applied Nonlinear Dynamical Systems and Chaos, Springer-Verlag, New York, 1990.

10. Pontryagin, L.S., The Mathematical Theory of Optimal Processes. New York John Willey \& Son, Inc. 1962.

\section{Lampiran}

Dengan mengacu cara (Pontryagin [10]) maka fungsi Hamiltonian dari model ini adalah:

$$
\begin{aligned}
H=\left(\left(w_{x}-w_{0 x}\right)\right. & \frac{\tau_{x} N X}{1+N}+\left(w_{y}-w_{0 y}\right) \frac{\tau_{y} N Y}{1+N}-w_{1} N \\
& \left.-w_{2 x} C_{x}-w_{2 y} C_{y}\right) e^{-\delta t} \\
& +\varphi_{1}\left(r_{x} X\left(1-\frac{X}{C_{x}}\right)\right. \\
& \left.-\tau_{x} X\left(1-\frac{1}{1+N}\right)\right) \\
& +\varphi_{2}\left(r_{y} Y\left(1-\frac{Y}{C_{y}}\right)\right. \\
& \left.-\tau_{y} Y\left(1-\frac{1}{1+N}\right)\right)
\end{aligned}
$$

dimana $\varphi_{1}, \varphi_{2}, \varphi_{3}$, dan $\varphi_{4}$ merupakan pengali lagrange. Berdasarkan Prinsip Maksimum Pontryagin, maka dalam kasus ini harus memenuhi kondisi $\frac{\partial H}{\partial N}=0,-\frac{\partial \varphi_{1}}{\partial t}=\frac{\partial H}{\partial X},-\frac{\partial \varphi_{2}}{\partial t}=\frac{\partial H}{\partial Y},-\frac{\partial \varphi_{3}}{\partial t}=\frac{\partial H}{\partial C_{x}}$ dan $-\frac{\partial \varphi_{4}}{\partial t}=\frac{\partial H}{\partial c_{y}}$. Sehingga, didapat kondisi optimal untuk model pengendalian persediaan yang memaksimumkan laba yaitu:

$$
\begin{gathered}
\left(\left(w_{x}-w_{0 x}\right) \frac{\tau_{x} X^{*}}{1+N}+\left(w_{y}-w_{0 y}\right) \frac{\tau_{y} Y^{*}}{1+N}-w_{1}\right) \\
-\left(\varphi_{1} \frac{\tau_{x} X^{*}}{(1+N)^{2}}+\varphi_{2} \frac{\tau_{y} Y^{*}}{(1+N)^{2}}\right) \\
-\left(\varphi_{3} \gamma_{x} C_{x}{ }^{*}+\varphi_{4} \gamma_{y} C_{y}{ }^{*}\right)=0
\end{gathered}
$$

dimana:

$$
\begin{gathered}
\varphi_{1}=-\left(w_{x}-w_{0 x}\right) \frac{\tau_{x} N}{(1+N)\left(-\delta+\lambda_{6}\right)^{\prime}} \\
\varphi_{2}=-\left(w_{y}-w_{0 y}\right) \frac{\tau_{y} N}{(1+N)\left(-\delta+\lambda_{5}\right)^{\prime}} \\
\varphi_{3}=\left(w_{2 x}+\left(w_{x}-w_{0 x}\right) \frac{\tau_{x} N r_{x}\left(1-\frac{\tau_{x} N}{r_{x}(1+N)}\right)^{2}}{(1+N)\left(-\delta+\lambda_{6}\right)}\right) \frac{1}{\left(\lambda_{3}-\delta\right)}
\end{gathered}
$$

dan

$$
\varphi_{4}=\left(w_{2 y}+\left(w_{y}-w_{0 y}\right) \frac{\tau_{y} N r_{y}\left(1-\frac{\tau_{y} N}{r_{y}(1+N)}\right)^{2}}{(1+N)\left(-\delta+\lambda_{5}\right)}\right) \frac{1}{\left(\lambda_{4}-\delta\right)}
$$

